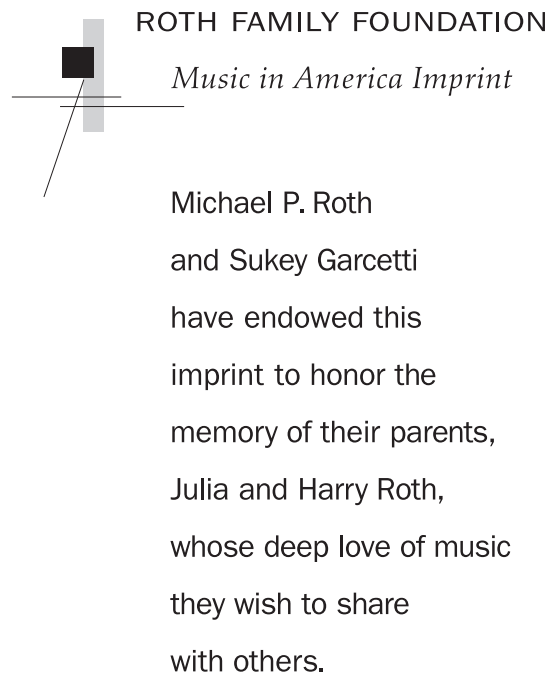


The publisher gratefully acknowledges the generous contribution to this book provided by the AMS 75 PAYS Endowment of the American Musicological Society, funded in part by the National Endowment for the Humanities and the Andrew W. Mellon Foundation. 
Blowin' the Blues Away 


\section{MUSIC OF THE AFRICAN DIASPORA}

Guthrie P. Ramsey, Jr., Editor

Samuel A. Floyd, Jr., Editor Emeritus

I. California Soul: Music of African Americans in the West, edited by Jacqueline Cogdell DjeDje and Eddie S. Meadows

2. William Grant Still: A Study in Contradictions, by Catherine Parsons Smith

3. Jazz on the Road: Don Albert's Musical Life, by Christopher Wilkinson

4. Harlem in Montmartre: A Paris Jazz Story between the Great Wars, by William A. Shack

5. Dead Man Blues: Jelly Roll Morton Way Out West, by Phil Pastras

6. What Is This Thing Called Jazz?: African American Musicians as Artists, Critics, and Activists, by Eric Porter

7. Race Music: Black Cultures from Bebop to Hip-Hop, by Guthrie P. Ramsey, Jr.

8. Lining Out the Word: Dr. Watts Hymn Singing in the Music of Black Americans, by William T. Dargan

9. Music and Revolution: Cultural Change in Socialist Cuba, byRobin D. Moore

Io. From Afro-Cuban Rhythms to Latin Jazz, by Raul A. Fernandez

I I. "Mek Some Noise": Gospel Music and the Ethics of Style in Trinidad, by Timothy Rommen

I2. The Memoirs of Alton Augustus Adams, Sr.: First Black Bandmaster of the United States Navy, edited with an introduction by Mark Clague, with a foreword by Samuel Floyd, Jr.

13. Digging: The Afro-American Soul of American Classical Music, by Amiri Baraka

I4. Different Drummers: Rhythm and Race in the New World, by Martin Munro

I 5. Funky Nassau: Roots, Routes, and Representation in Bahamian Popular Music, by Timothy Rommen

16. Blowin' the Blues Away: Performance and Meaning on the New York Jazz Scene, by Travis A. Jackson 


\section{Blowin' the Blues Away}

Performance and Meaning on the

New York Jazz Scene

\section{Travis A. Jackson}

\section{甲}

UNIVERSITY OF CALIFORNIA PRESS

Berkeley • Los Angeles • London 
University of California Press, one of the most distinguished university presses in the United States, enriches lives around the world by advancing scholarship in the humanities, social sciences, and natural sciences. Its activities are supported by the UC Press Foundation and by philanthropic contributions from individuals and institutions. For more information, visit www.ucpress.edu.

University of California Press Berkeley and Los Angeles, California

University of California Press, Ltd. London, England

(C) 2012 by The Regents of the University of California

Early versions of portions of chapters 5 and 6 appeared as "Jazz Performance as Ritual: The Blues Aesthetic and the African Diaspora" in The African Diaspora: A Musical Perspective, ed. Ingrid Monson, 23-82 (New York: Garland, 2000).

\section{Library of Congress Cataloging-in-Publication Data}

Jackson, Travis A.

Blowin' the blues away : performance and meaning on the New York jazz scene / Travis A. Jackson.

p. $\mathrm{cm}$. - (Music of the African diaspora)

Includes bibliographical references and index.

ISBN 978-0-520-27044-2 (cloth : alk. paper) ISBN 978-0-520-27045-9 (pbk. : alk. paper)

I. Jazz-New York (State)-New York-History and criticism. I. Title.

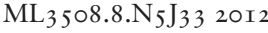

781.6509747'109049-dc23

Manufactured in the United States of America

\begin{tabular}{|c|c|c|c|c|c|c|c|}
\hline 20 & I9 & I 8 & I7 & I6 & I 5 & I4 & I3 \\
\hline IO & 9 & 8 & 6 & 5 & 4 & 2 & I \\
\hline
\end{tabular}

In keeping with a commitment to support environmentally responsible and sustainable printing practices, UC Press has printed this book on 50-pound Enterprise, a $30 \%$ post-consumer-waste, recycled, deinked fiber that is processed chlorine-free. It is acid-free and meets all ANSI/NISO (Z 39.48) requirements. 
To Lawrence Jackson Sr. and to the memory of Sherryl L. Jackson, Rev. Chalmers Jackson Sr., and Robert Thomas Hodge-each of whom opened a way for me 
